\title{
UJI AKTIVITAS ANTIOKSIDAN EKSTRAK ETANOL 70\% DAUN MATOA (Pometia pinnata) TERHADAP AKTIVITAS ALT DAN AST DARAH TIKUS PUTIH YANG DIINDUKSI KARBON TETRAKLORIDA $\left(\mathrm{CCl}_{4}\right)$
}

\author{
Try Oktavia Djabar
}

tryoktaia911@gmail.com, Puskesmas Gotowasi, Kec. Maba Selatan. Halmahera Timur

\begin{abstract}
Antioxidant is a molecule that capable stabilize or deactivate free radicals in order not to make the cells demaged. Flavonoid compounds have pharmacological effects as antioxidants the one is leaf of Matoa (Pometia pinnata). This study aims to look the activities of antioxodant $70 \%$ ethanol extract Matoa leaves (Pometia pinnata) in liver of male rats induced by $\mathrm{CCl}_{4}$. Experiments was conducted 16 days with 30 rats were divided into 6 group. The group $\mathrm{KN}$ and $\mathrm{KKN}$ that are given distilled water for 5 days; The group of KKP that is given treatment with curcuma $81 \mathrm{mg} / \mathrm{kg}$ BB for 10 days; The group of KE1, KE2 and KE3 that were given $70 \%$ ethanol extract Matoa leaves (Pometia pinnata) (KE1 dose I $100 \mathrm{mg} / \mathrm{kg} \mathrm{BW}$ of rats, KE2 dose II $200 \mathrm{mg} / \mathrm{kg}$ BB of rats and KE3 dose III $400 \mathrm{mg} / \mathrm{kg} \mathrm{BW}$ of rats) for 10 days. All of the group except $\mathrm{KN}$ was induced by $\mathrm{CCl}_{4} 0,05 \mathrm{mg} / \mathrm{kg} \mathrm{BW}$ for 5 days. On day 16 all rats blood were taken and than measured the the activity of alanine aminotransferase (ALT) and aspartate aminotransferase (AST). The test results of the analysis using one way ANOVA. Increase level of ALT and AST has been seen in the dose $100 \mathrm{mg} / \mathrm{kg} \mathrm{BW}$ and increased antioxidant activity at dose $400 \mathrm{mg} / \mathrm{kg} \mathrm{BW}$.

Keyword : Antioxidant, Matoa leaves (Pometia pinnata), ALT, AST.
\end{abstract}

\begin{abstract}
Abstrak
Antioksidan merupakan molekul yang mampu menstabilkan atau menonaktifkan radikal bebas agar tidak merusak sel. Senyawa kimia flavonoid mempunyai efek farmakologik sebagai antioksidan salah satunya adalah Daun matoa (Pometia pinnata). Penelitian ini bertujuan untuk melihat aktifitas antioksidan ekstrak etanol $70 \%$ daun matoa pada hati tikus putih jantan yang diinduksi $\mathrm{CCl}_{4}$. Perlakuan dilakukan selama 16 hari dengan 30 ekor tikus dibagi 6 perlakuan, kelompok KN dan KKN diberikan aquadest selama 5 hari; kelompok KKP diberi pembanding curcuma $81 \mathrm{mg} / \mathrm{kg}$ BB selama 10 hari; kelompok KE1, KE2 dan KE3 diberikan ekstrak etanol 70\% daun matoa masing-masing KEI dosis I (100 mg/kg BB tikus), KE2 dosis II (200 mg/kg BB tikus) dan KE3 dosis III (400 $\mathrm{mg} / \mathrm{kg} \mathrm{BB}$ tikus) selama 10 hari. Semua kelompok kecuali $\mathrm{KN}$ di induksi dengan $\mathrm{CCl}_{4}$ dosis $0,05 \mathrm{mg} / \mathrm{kg} \mathrm{BW}$ selama 5 hari. Pada hari ke-16, dilakukan pengambilan darah dan kemudian dilakukan pemeriksaan kadar Alanin aminotransferase (ALT) dan Aspartat aminotransferase (AST). Analisis statistik menggunakan One Way Anova. Peningkatan kadar ALT dan AST sudah dapat terlihat pada pemberian dosis $100 \mathrm{mg} / \mathrm{kg}$ BB dan aktivitas antioksidannya semakin meningkat pada dosis $400 \mathrm{mg} / \mathrm{kg}$ BB.
\end{abstract}

Kata kunci : Antioksidan, Daun matoa (Pometia pinnata), ALT, AST.

\section{PENDAHULUAN}

Antioksidan memiliki manfaat yang positif dan berperan penting dalam menjaga kesehatan tubuh. Hal ini disebabkan karena kemampuan antioksidan dalam menangkap radikal bebas (Shivaprasad, 2005). Radikal bebas yang berlebihan akan mengakibatkan terjadinya stres oksidatif karena kurangnya jumlah antioksidan dalam tubuh sehingga dapat menumbulkan berbagai penyakit (Shivaprasad, 2005; Rohdiana, 2001). Antioksidan dapat mencegah dan mengobati berbagai penyakit yang diakibatkan oleh hantaman radikal bebas dari luar tubuh, seperti polusi udara, merokok, zat-zat kimia serta paparan sinar ultraviolet. Antioksidan berdasarkan sumbernya terdiri dari dua golongan, yaitu antioksidan sintetik dan antioksidan alami yang merupakan hasil isolasi bahan alam. Adanya kekhawatiran akan kemungkinan efek samping dari antioksidan sintetik menyebabkan antioksidan alami menjadi antioksidan yang sangat dibutuhkan (Rohdiana, 2001).

Matoa adalah tanaman yang belum dimaksimalkan manfaatnya sebagai tanaman obat. Matoa (Pometia pinnata) merupakan tanaman khas dari Papua Barat. Berdasarkan penelitian sebelumnya, diketahui bahwa ekstrak kulit buah matoa (Pometia pinnata) memiliki aktivitas 
antibakteri dan antioksidan (Faustina, 2013). Sedangkan, kulit batang dari matoa (Pometia pinnata) mengandung senyawa metabolit sekunder seperti tannin, flavonoid, terpenoid dan saponin serta memiliki aktivitas antibakteri (Mercy, 2013). Senyawa kimia seperti flavonoid diketahui sebagai senyawa dengan efek farmakologi yang cukup tinggi, diantaranya sebagai antibakteri, antioksidan dan antijamur (Thitilerdecha et.al., 2008; Kawamura et.al., 2010).

Daun matoa (Pometia pinnata) diketahui mengandung senyawa golongan flavonoid (Jayuska dkk., 2013) yang diduga dapat berkhasiat sebagai antioksidan. Namun, sejauh ini belum ada penelitian tentang aktivitas antioksidan dari daun Matoa (Pometia pinnata).

Penelitian ini bertujuan untuk mengetahui efek antioksidan dari ekstrak daun Pometia pinnata secara in vivo dengan parameter yang dilihat adalah aktivitas ALT dan AST dalam darah. Penelitian ini menggunakan $\mathrm{CCl}_{4}$ sebagai penginduksi stres oksidatif yang umum digunakan. Karbon tetraklorida merupakan suatu senyawa kimia yang dapat merusak jaringan. Efek toksik $\mathrm{CCl}_{4}$ yang timbul disebabkan karena terbentuknya senyawa radikal bebas yang dapat merusak membaran sel. Dalam hati $\mathrm{CCl}_{4}$ akan dimetabolisme oleh sitokrom $\mathrm{P} 450$ membentuk senyawa radikal bebas triklorometil $\left(\mathrm{CCl}_{3}{ }^{*}\right)$, kemudian senyawa ini akan dengan cepat bereaksi terhadap oksigen sehingga membentuk radikal triklorometil peroksil $\left(\mathrm{CCl}_{3} \mathrm{O}_{2}{ }^{-*}\right)$ yang bersifat sangat reaktif dan dapat mengoksidasi asam-asam lemak tak jenuh pada membran, sehingga menimbulkan peroksidasi lipid yang menyebabkan kerusakan pada struktur dan fungsi dari membran sel (Halliwel dan Gutteridge, 2007; Noer, 1996).

Kerusakan akibat radikal bebas yang terjadi pada membran sel, khususnya sel hati dapat mempengaruhi protein intra sel, diantaranya enzim. ALT dan AST merupakan enzim intra sel yang banyak terdapat pada sel hati dan merupakan enzim plasma non fungsional. Enzim plasma non fungsional adalah enzim yang secara fisiologis tidak melakukan fungsi di jaringan dan kadarnya sangat rendah di plasma dibandingkan dengan kadar di jaringan. Jika terjadi kerusakan pada jaringan, maka enzim ini akan memasuki sirkulasi darah dengan kadar yang signifikan, sehingga hal ini dapat dijadikan dasar pemeriksaan yang mengindikasikan adanya kerusakan sel (Murray et al, 2009). Penelitian ini diharapkan dapat menjadi masukan yang berguna bagi masyarakat dan dapat melengkapi fitofarmaka Indonesia.

\section{METODOLOGI}

\section{Alat dan Bahan}

Bahan yang digunakan adalah daun matoa (Pometia pinnata) yang diambil dari Balai Penelitian Tanaman Rempah dan Obat (BALITRO). Sampel daun tanaman Matoa (Pometia pinnata) diindentifikasikan di Herbarium Bogoriense Bidang Botani Pusat Penelitian Biologi, Lembaga Ilmu Pengetahuan Indonesia (LIPI) Bogor, untuk memastikan keaslian jenis tumbuhan. Pembuatan ekstrak menggunakan metode Ekstraksi Maserasi dengan pelarut etanol 70\%. Curcuma (SOHO) sebagai standar pembanding dan Karbon Tetraklorida $\left(\mathrm{CCl}_{4}\right)$ sebagai penginduksi. Pelarut yang digunakan adalah Aquadestilata, Etanol, Minyak Kelapa. Pemeriksaan aktivitas ALT dan AST menggunakan Kit ALT/AST (DyaSis®). Hewan uji yang digunakan adalah tikus putih jantan galur Spraygue Dawley dengan berat 150 sampai 250 gram yang diperoleh dari Blitar yang sudah diperiksa kesehatannya oleh Dinas Peternakan Pemerintah Provinsi Jawa Timur.

\section{Cara kerja}

\section{Pembuatan ekstrak}

Simplisia daun Matoa (Pometia pinnata) diekstraksi menggunakan metode maserasi dengan pelarut etanol $70 \%$. Daun yang telah kering, dihaluskan dan ditimbang kurang lebih sebanyak $500 \mathrm{~g}$ kemudian dimaserasi dengan etanol 70\%, volume pelarut etanol harus melebihi batas simplisia $( \pm 2 \mathrm{~cm}$ ) dari permukaan simplisia). Tutup wadah maserasi dengan alumunium foil dan diaduk dengan stirer selama 3 jam, lakukan maserasi selama 24 jam, kemudian saring 
dengan kertas saring untuk memisahkan filtrate (1) dengan residu. Proses maserasi dilakukan berulang dengan 2 kali penggantian pelarut pada residu hasil penyaringan. Selanjutnya filtrat $(1 \& 2)$ hasil maserasi digabungkan dan diuapkan pelarutnya (evaporasi) menggunakan Rotary Evaporator, sehingga diperoleh ekstrak kental daun Matoa (Pometia pinnata).

\section{Pemeriksaan karakteristik ekstrak}

Ekstrak etanol 70\% daun Matoa (Pometia pinnata) yang diperoleh dihitung randemen ekstrak, pemeriksaan organoleptik dan dilakukan uji sisa pelarut, tujannya adalah memberikan jaminan bahwa selama proses tidak meninggalkan sisa pelarut yang memang seharusnya tidak boleh ada, kemudian pemeriksaan kandungan kimia pada ekstrak meliputi alkaloid, flavonoid, tannin dan saponin.

\section{Perlakuan Kelompok Hewan Uji}

Penelitian ini menggunakan rancangan acak lengkap masing-masing 30 ekor tikus dibagi menjadi 6 perlakuan dalam 5 kali ulangan. Kelompok normal (KN) diberikan aquadest selama 5 hari (hari 1-5); sedangkan kelompok kontrol negatif (KKN) dibuat stres oksidatif dengan Karbon Tetraklorida $\left(\mathrm{CCl}_{4}\right)$ dosis $0,05 \mathrm{mg} / \mathrm{kg} \mathrm{BB}$ dalam $1 \mathrm{~mL}$ minyak kelapa selama 5 hari (hari 1-5); kelompok kontrol positif (KKP) diberikan $\mathrm{CCl}_{4}$ dosis $0,05 \mathrm{mg} / \mathrm{kg} \mathrm{BB}$ dalam 1 $\mathrm{mL}$ minyak kelapa selama 5 hari (hari 1-5) dan diberikan larutan pembanding curcuma 81 $\mathrm{mg} / \mathrm{kg}$ BB selama 10 hari (hari 6-15); kelompok ekstrak dosis I (KE1) diberikan $\mathrm{CCl}_{4}$ dosis $0,05 \mathrm{mg} / \mathrm{kg} \mathrm{BB}$ dalam $1 \mathrm{~mL}$ minyak kelapa selama 5 hari (hari 1-5) dan diberikan sediaan ekstrak etanol 70\% daun matoa (Pometia pinnata) dosis I (100 mg/kg BB tikus) selama 10 hari (hari 6-16); kelompok ekstrak dosis II (KE2) diberikan $\mathrm{CCl}_{4}$ dosis $0,05 \mathrm{mg} / \mathrm{kg}$ bb dalam $1 \mathrm{~mL}$ minyak kelapa selama 5 hari (hari 1-5) dan diberikan sediaan ekstrak etanol $70 \%$ daun matoa (Pometia pinnata) dosis II (200 mg/kg BB tikus) selama 10 hari (hari 6-15); dan kelompok ekstrak dosis III (KE3) diberikan $\mathrm{CCl}_{4}$ dosis $0,05 \mathrm{mg} / \mathrm{kg}$ BB dalam $1 \mathrm{~mL}$ minyak kelapa selama 5 hari (hari 1-5) dan diberikan sediaan ekstrak etanol $70 \%$ daun matoa (Pometia pinnata) dosis III (400 mg/kg BB tikus) selama 10 hari (hari 6-15). Pada hari ke-16, dilakukan pengambilan darah dan pemeriksaan kadar Alanin aminotransferase (ALT) dan Aspartat aminotransferase (AST).

\section{Pengambilan sampel darah}

Darah diambil melalui vena jugularis, darah yang diperoleh ditampung di dalam tabung EDTA dan disentrifugasi dengan kecepatan 3000 rpm selama 10 menit. plasma yang diperoleh dari hasil sentrifugasi diambil atau dipisahkan menggunakan pipet.

\section{Penetapan aktivitas ALT dan AST (Dyasis $\left.{ }^{\circledR}\right)$}

Penetapan aktivitas ALT dan AST berdasarkan reaksi enzimatik menggunakan reagen kit Dyasis ${ }^{\circledR}$ ALT. Larutan sampel berisi campuran reagen 1 (R1) dan reagen 2 (R2) dengan perbandingan $4: 1$, kemudian sebanyak $1000 \mu 1$ reagen kit AST tersebut direaksikan dengan $100 \mu \mathrm{l}$ sampel, divortex dan diinkubasi pada suhu $37^{\circ} \mathrm{C}$ selama 1 menit, selanjutnya sampel dibaca absorbansinya menggunakan spektrofotometer UV-Vis pada panjang gelombang 365 nm.

\section{Analisa Data}

Data dianalisa menggunakan anova satu arah program SPSS. Jika data tidak terdistribusi normal atau tidak bervarians homogen maka digunakan metode Kruskal wallis.

\section{HASIL DAN PEMBAHASAN}

Hasil rendemen ekstrak yang diperoleh dari proses ekstraksi sebesar 53,28\%. Pemeriksaan organoleptik ekstrak etanol $70 \%$ daun Matoa (Pometia pinnata) secara organoleptik menunjukkan bahwa ekstrak memiliki konsistensi yang kental, berwarna coklat kehitaman, berbau khas dan berasa pahit kelat dan sedikit berbusa. Pemeriksaan kadar sisa pelarut pada ekstrak etanol $70 \%$ daun Matoa (Pometia pinnata) adalah 0,01\%. Hal ini 
menunjukkan bahwa kadar pelarut etanol $70 \%$ yang tersisa dalam ekstrak hanya sebesar $0,01 \%$ sehingga masih memenuhi persyaratan batas sisa pelarut etanol yang diperbolehkan yakni menurut FDA (Food and Drug Administration) adalah 0,5\%. Berdasarkan hasil skrining senyawa fitokimia, ekstrak etanol $70 \%$ daun Matoa (Pometia pinnata) positif mengandung beberapa kelompok senyawa kimia, seperti senyawa alkaloid, saponin, tanin, terpenoid dan khususnya senyawa flavonoid yang diduga dapat berkhasiat sebagai antioksidan. Hasil pemeriksaan rata-rata aktivitas AST dan ALT Hati tikus pada gambar 1 dan gambar 2.

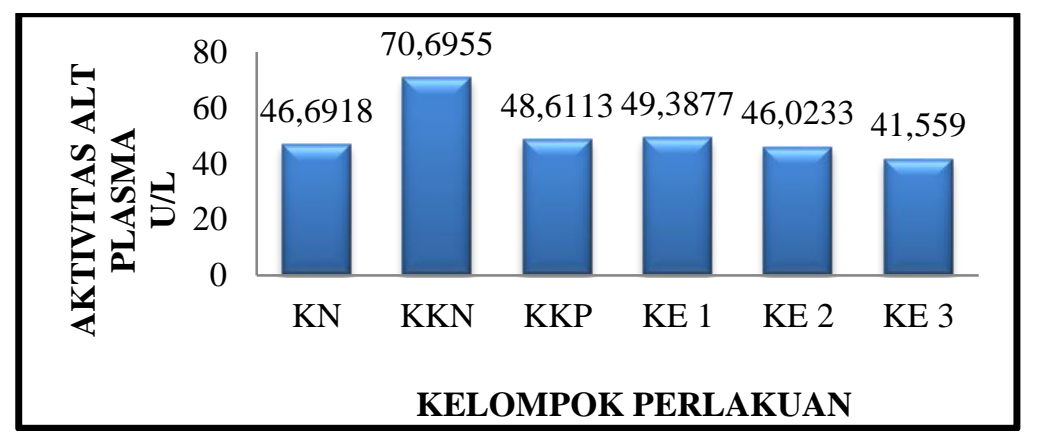

Gambar 1. Grafik perbandingan aktivitas ALT plasma darah

Berdasarkan hasil pemeriksaan aktivitas ALT plasma darah Pada gambar 1 terlihat aktivitas ALT plasma yang diperoleh dari kelompok KN adalah 46,69 U/L, aktivitas ALT pada $\mathrm{KN}$ lebih rendah dibanding aktivitas $\mathrm{ALT}$ pada $\mathrm{KKN}$ yang diinduksi $\mathrm{CCl}_{4}$, yaitu 70,69 U/L. Pada KKP yang diberikan Curcuma (SOHO) setelah pemberian $\mathrm{CCl}_{4}$ dengan dosis $81 \mathrm{mg} / \mathrm{Kg}$ BB, aktivitas ALT plasma lebih rendah dibanding kelompok KKN, yaitu 48.6113 U/L. Pada KE1 yang diberikan ekstrak etanol $70 \%$ daun Matoa dengan dosis $100 \mathrm{mg} / \mathrm{Kg}$ BB setelah pemberian $\mathrm{CCl}_{4}$, aktivitas ALT plasma darah yang diperoleh lebih rendah dibanding KKN yaitu 49,3877 U/L, tetapi lebih tinggi dibanding KN. Pada KE2 dan KE3 yang diberikan ekstrak etanol 70\% daun Matoa dengan dosis $200 \mathrm{mg} / \mathrm{Kg}$ BB dan dosis $400 \mathrm{mg} / \mathrm{Kg}$, memperlihatkan aktivitas ALT dalam plasma yang lebih rendah dibanding KKN dan hampir sama dengan aktivitas ALT pada KN, yaitu berturut-turut 46,0233 U/L dan 41.559 U/L.

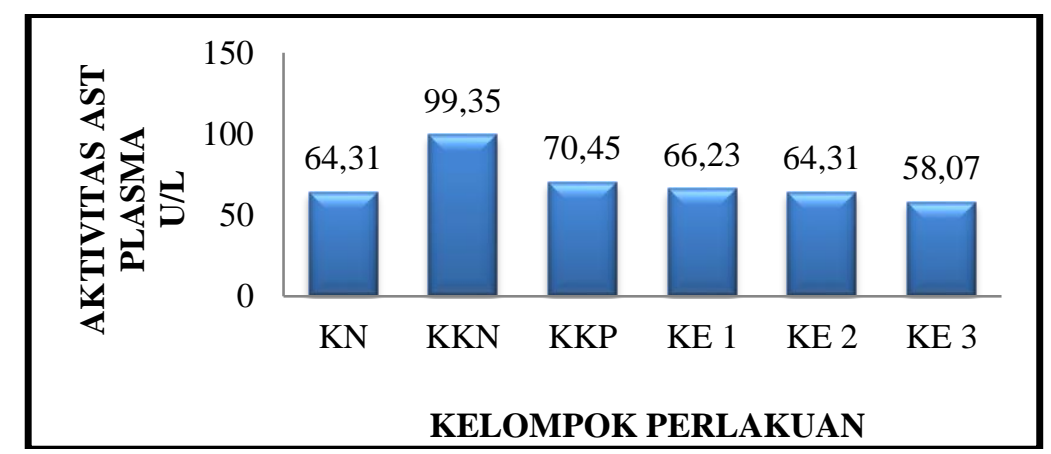

Gambar 2. Grafik perbandingan aktivitas AST plasma darah

Pada gambar 2 terlihat bahwa aktivitas AST plasma yang diperoleh dari KN, yaitu 64,31 U/L lebih rendah dari aktivitas AST pada $\mathrm{KKN}$ yang diinduksi $\mathrm{CCl}_{4}$, yaitu 99,35 U/L. Pada $\mathrm{KKP}$ yang diberikan Curcuma (SOHO) setelah pemberian $\mathrm{CCl}_{4}$ dengan dosis $81 \mathrm{mg} / \mathrm{Kg} \mathrm{BB}$, aktivitas AST plasma lebih rendah dibanding KKN, yaitu 70,45 U/L, tetapi lebih tinggi dibanding KN. Pada KE1 yang diberikan ekstrak etanol 70\% daun Matoa dengan dosis 100 $\mathrm{mg} / \mathrm{Kg} \mathrm{BB}$, aktivitas AST plasma darah yang diperoleh lebih rendah dibanding KKN yaitu 66,23 U/L, sama halnya dengan KE2 dan KE3 yang diberikan ekstrak etanol 70\% daun Matoa dengan dosis $200 \mathrm{mg} / \mathrm{Kg} \mathrm{BB}$ dan dosis $400 \mathrm{mg} / \mathrm{Kg}$ dengan rata-rata aktivitas AST plasma darah 
64,31 U/L dan 58,07 U/L yang memperlihatkan aktivitas AST lebih rendah dari aktivitas AST pada KKN.

Hasil analisis statistik aktivitas ALT dan aktivitas AST pada plasma darah menggunakan ANOVA menunjukkan tingginya aktivitas ALT dan AST plasma darah tikus pada kelompok tikus yang diinduksi $\mathrm{CCl}_{4}(\mathrm{KKN})$ berbeda bermakna $(\mathrm{p}<0,05)$ bila dibandingkan dengan KN. Pada KKP yang diberikan curcuma sebagai pembanding terdapat perbedaan bermakna aktivitas ALT dan aktivitas AST dengan KKN ( $<<0,05)$, sedangkan pada kelompok yang diberikan ekstrak etanol 70\% daun Matoa (Pometia pinnata) KE1, KE2, KE3 dengan dosis berturut-turut $100 \mathrm{mg} / \mathrm{Kg} \mathrm{BB}, 200 \mathrm{mg} / \mathrm{Kg} \mathrm{BB}$ dan $400 \mathrm{mg} / \mathrm{Kg} \mathrm{BB}$, terlihat perbedaan bermakna $(\mathrm{p}<0,05)$ tehadap kelompok KKN. Tetapi tidak terdapat perbedaan bermakna $(\mathrm{p}>0,05)$ dengan KN dan KKP.

Tingginya aktivitas ALT dan AST dipengaruhi karena banyaknya radikal bebas yang terbentuk dari hasil metabolisme $\mathrm{CCl}_{4}$ yang menyebabkan kerusakan membran sel hati akibat peroksidasi lipid, sehingga menyebabkan kerusakan struktur membran dan permeabilitas membran sel hati terganggu. Walaupun sel hati memiliki mekanisme pertahanan antioksidan endogen, tetapi karena tingginya stres oksidatif di dalam sel maka antioksidan endogen tidak dapat menahan kerusakan pada organ hati. Kerusakan pada sel-sel hati menyebabkan ALT dan AST yang banyak terkandung di dalam sel-sel hati akan keluar, sehingga aktivitasnya akan meningkat pada plasma. Dalam hati $\mathrm{CCl}_{4}$ akan dimetabolisme oleh sitokrom P450 membentuk senyawa radikal bebas triklorometil $\left(\mathrm{CCl}_{3}{ }^{*}\right)$, kemudian senyawa ini akan dengan cepat bereaksi terhadap oksigen sehingga membentuk radikal triklorometil peroksil $\left(\mathrm{CCl}_{3} \mathrm{O}_{2}{ }^{-*}\right)$ yang bersifat sangat reaktif dan dapat mengoksidasi asam-asam lemak tak jenuh pada membran, sehingga menimbulkan peroksidasi lipid yang menyebabkan kerusakan pada struktur dan fungsi dari membran sel (Halliwel dan Gutteridge, 2007; Noer, 1996).

Kenaikan aktivitas ALT dan AST dalam plasma dapat disebabkan oleh sel-sel yang kaya akan transaminase mengalami nekrosis atau hancur, sehingga enzim tersebut masuk ke dalam peredaran darah. Oleh karena itu, tingginya aktivitas ALT dan AST dalam plasma dapat dijadikan indikator adanya kerusakan sel, seperti sel hati (Halliwell dan Gutteridge, 2007; Noer, 1996).

Pemberian ekstrak etanol 70\% daun Matoa menggunakan tiga dosis berbeda, yaitu 100, 200 dan 400 mg/Kg BB. Dari ketiga dosis tersebut semuanya menunjukkan penurunan aktivitas ALT dan AST pada plasma hingga mencapai aktivitas normal. Sehingga dapat disimpulkan bahwa ekstrak etanol $70 \%$ daun Matoa (Pometia pinnata) memiliki aktivitas antioksidan sehingga dapat menekan stres oksidatif.

\section{PENUTUP}

Pemberian ekstrak etanol 70\% daun matoa dosis $100 \mathrm{mg} / \mathrm{kg} \mathrm{BB}, 200 \mathrm{mg} / \mathrm{kg} \mathrm{BB}$ dan 400 $\mathrm{mg} / \mathrm{kg}$ BB dapat menurunkan aktivitas ALT dan AST pada darah tikus putih jantan yang diinduksi $\mathrm{CCl}_{4}$. Penurunan aktivitas ALT dan AST telah terlihat pada pemberian dosis 100 $\mathrm{mg} / \mathrm{kg} \mathrm{BB}$ dan aktivitas antioksidannya semakin meningkat hingga dosis $400 \mathrm{mg} / \mathrm{kg} \mathrm{BB}$.

\section{DAFTAR PUSTAKA}

Faustina, F.C.. (2013). Major Components in Matoa Fruit Peel and The Antioxidant and Antimicrobial Activity of Its Extract, Swiss German University.

Jayuska, A., Sayekti, E., Rahimah. (2013). Karakterisasi Senyawa Flavonoid Hasil Isolat dari Fraksi Etil Asetat Daun Matoa (Pometia pinnata)[skripsi]. Universitas Tanjung Pura.

Halliwell, B. dan Gutteridge, J.M.C. (2007). Free Radicals in Biology and Medicine, $4^{\text {th }}$ ed. London, University Press, Oxford. 
Kawamura, F., Shaharuddin, N.A., Sulaiman, O. Hashim, R., and Ohara, S. (2010). Evaluation on Antioxidant Activity, Antifungal Activity and Total Phenol of 11 Selected Commercial Malaysian Timber Species, JARQ 44 (3), 319-324.

Murray, R.K., Granner, D.K. dan Rodwell, V.W. (2006). Biokimia Harper ed. 27, Penerbit Buku Kedokteran EGC, Jakarta.

Noer, H.M.S., dkk. (1996) Buku Ajar Ilmu Penyakit Dalam, Jilid I, edisi ketiga. Balai Penerbit FKUI, Jakarta. 224-332.

Rohdiana, D. (2001). Aktivitas Daya Tangkap Radikal Polifenol Dalam Daun Teh, Majalah Jurnal Indonesia12, (1),53-58.

Roykhan, A. (2012). Efek Ekstrak Etanol Kulit Rambutan (Nephelium lappaceum L.) Terhadap Pencegahan peningkatan Kadar Enzim Transaminase Pada Tikus Putih (Ratus norvegicus) Jantan yang Diinduksi Karbon Tetraklorida $\left(\mathrm{CCl}_{4}\right)$ [Skripsi].Universitas Islam Indonesia, Yogyakarta.

Shivprasad, H.N. (2005). In-vitro models for antioxidant activity evaluation: a review. Pharmaceutical Rev,(3).

Thitilertdecha, N., Teerawutgulrag, A., Rakariyatham, N. (2008). Antioxidant and antibacterial activities of Nephelium lappaceum L. Extracts., LWT Food Sci. Tecnol, 41, 2028-2035. 